\title{
Trophic Cascading of Medusae on the Relationships between Copepods and Diatoms in a Subtropical Coastal Ecosystem
}

\author{
Jia-Lu Chung ${ }^{1}$, Fuh-Kwo Shiah ${ }^{1,2,3,{ }^{*} \text {, Gwo-Ching Gong }}{ }^{2,4}$, and Kuo-Ping Chiang ${ }^{2}$ \\ ${ }^{1}$ Institute of Oceanography, National Taiwan University, Taipei, Taiwan, ROC \\ ${ }^{2}$ Institute of Marine Environmental Chemistry and Ecology, National Taiwan Ocean University, Keelung, Taiwan, ROC \\ ${ }^{3}$ Research Center for Environmental Changes, Academia Sinica, Taipei, Taiwan, ROC \\ ${ }^{4}$ Taiwan Ocean Research Institute, National Applied Research Laboratories, Taipei, Taiwan, ROC
}

Received 9 November 2007, accepted 23 May 2008

\begin{abstract}
To investigate the spatial and temporal variation of phytoplankton and copepods, eight seasonal cruises (January 2005 October 2006) were conducted in a subtropical coast site that encompassed 19 sampling stations. The results indicated that the temperature $\left(18.4-29.7^{\circ} \mathrm{C}\right)$ varied more than $10^{\circ} \mathrm{C}$ seasonally, while nutrient concentrations (nitrate: $0.4-6.3 \mu \mathrm{M}$, phosphate: $0.1-0.8 \mu \mathrm{M}$, and silicate $2.1-12.1 \mu \mathrm{M})$ were inversely correlated with temperature. Diatoms $\left(2792-1602437 \mathrm{cells}^{-3}\right)$ constituted $>90 \%$ of the phytoplankton assemblages and dinoflagellates $\left(226-10029\right.$ cells m$\left.^{-3}\right)$ represented only $\sim 10 \%$ of the algae biomass. Copepod abundance $\left(8-1031\right.$ ind. $\left.\mathrm{m}^{-3}\right)$ varied positively with that of diatom and temperature. The relative abundance of Temora spp. $\left(1-712\right.$ ind. $\left.\mathrm{m}^{-3}\right)$ varied from $<2 \%$ in winter to $>69 \%$ in summer; that of Paracalanus spp. $(0.1$ 176 ind. $\left.\mathrm{m}^{-3}\right)$ were $>25 \%$ in spring and autumn and Calanus spp. $\left(0.5-24\right.$ ind. $\left.\mathrm{m}^{-3}\right)$ dominated in winter and spring, but accounted for only $\sim 10 \%$ of the total copepods. Both diatom density and copepod abundance were positively correlated with temperature, indicating these two plankton groups were left bottom-up control. The copepod abundance positively co-varied with diatoms in 2005, but not in 2006. Further season-to-season analysis showed that the diatom vs. copepod ratios changed positively only when the medusa abundance changed greatly ( $>40$-fold) between consecutive seasons. During periods when the medusa abundance varied less than 10 -fold between seasons, there is no relationship between the ratios and the medusa abundance. This study suggests that the stability of the medusa abundance from season to season could be important in regulating the ecological linkage between diatoms and their predators - copepods.
\end{abstract}

Key words: Copepods, Phytoplankton, Cascading effect, Eutrophic, Temperature control

Citation: Chung, J. L., F. K. Shiah, G. C. Gong, and K. P. Chiang, 2009: Trophic cascading of medusae on the relationships between copepods and diatoms in a subtropical coastal ecosystem. Terr. Atmos. Ocean. Sci., 20, 547-556, doi: 10.3319/TAO.2008.05.23.01(Oc)

\section{INTRODUCTION}

Copepods are the most dominant and most widely distributed mesozooplankton (size $>200 \mu \mathrm{m}$ ) in marine ecosystems. They can graze on phytoplankton and microzooplankton (size $<200 \mu \mathrm{m}$, e.g., protozoan), and play important roles in planktonic trophodynamics and organic carbon cycling (Calbet 2001; Calbet and Saiz 2005). Since herbivorous copepods are the major predator of phytoplankton, intuitively one may expect a certain statistical relationship between their abundances on different temporal and/or spatial scales (Davis 1987; Runge 1988; Cushing 1989; Mc-

\footnotetext{
* Corresponding author

E-mail:fkshiah@rcec.sinica.edu.tw
}

Laren et al. 1989; Gislason and Astthorsson 1995).

Copepods that graze on phytoplankton have been studied extensively in estuaries and coastal systems (Bautista and Harris 1992; Dagg 1995; Sautour et al. 1996; Hwang et al. 1998; Sautour and Castel 1999; Froneman 2000, 2001; Liu and Dagg 2003). Several studies of copepod have been conducted at the sampling site of this study (i.e., the Tan-Shui estuary), emphasizing the seasonal variation of species composition (Hsieh and Chiu 1997; Hwang et al. 2006; Dur et al. 2007), physical effects (monsoon and the mixing of water masses) and the effect of pollution (Fang et al. 2006) on the spatial and temporal pattern. However, the spatial and temporal variation of copepods and their rela- 
tionships with food sources (phytoplankton) and predators (medusae) at the Tan-Shui estuary have seldom been explored.

In the natural environment, copepods are also subjected to intensive predation pressure. Macrozooplankton medusae (or jellyfishes) are their most common predators (Matsakis and Conover 1991; Purcell 1992; Schneider and Behrends 1994; Olesen 1995; Nielsen et al. 1997). The cascading theory states that in a system with more than 3 trophic levels, the temporal variations of trophic levels 1 and 3 will be much alike with each other. Many studies have demonstrated this theory in marine systems, showing that jellyfish may cause a shift in the trophic structure of the pelagic community as a result of trophic cascading (Behrends and Schneider 1995; Schneider and Behrends 1998; Stibor et al. 2003). The aforementioned studies have addressed the cascading effects on temporal scales, while their potential effects on the spatial variability of lower trophic levels have seldom been emphasized. However, the applicability of this theory to eutrophic coastal and estuarine systems has not been demonstrated until recently.

A total of eight cruises were conducted in 2005 and 2006 in a subtropical eutrophic estuary. The collected alga, copepod and, physical and chemical data were analyzed to improve our understanding of the tropho-dynamics among copepods, medusae and algae in a subtropical estuary.

\section{MATERIAL AND METHODS}

\subsection{Study Site and Sampling}

Samples were collected from eight cruises conducted from January 2005 to October 2006. A total of 19 sampling stations were occupied outside the mouth of the Tan-Shui River (Fig. 1). ACTD-Rosette assembly (General Oceanics)

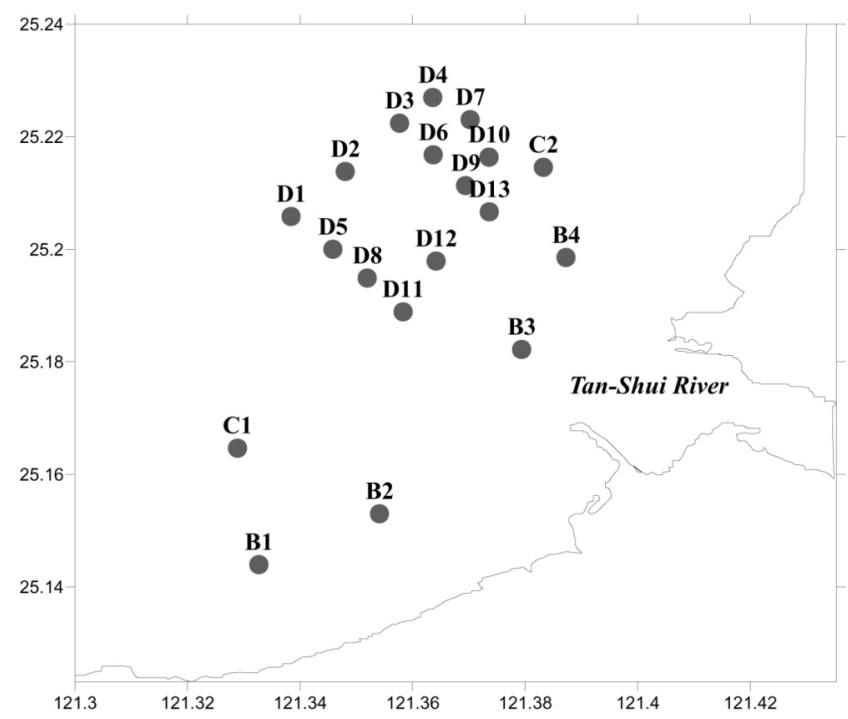

Fig. 1. Map of the 19 sampling stations outside the Tan-Shui River. equipped with 20-1 Go-Flo bottles was employed to record temperature and salinity as well as to collect water samples. The chemical and biological variables described below were all derived from the surface ( $2 \mathrm{~m}$ below surface) water samples.

\subsection{Inorganic Nutrients and Chlorophyll Concentrations}

Water samples for the determination of nutrient concentration were placed in $100 \mathrm{ml}$ polypropylene bottles, frozen instantly in liquid nitrogen, and stored in a freezer. Nutrients were analyzed with a self-designed flow injection analyzer (Strickland and Parsons 1972; Gong et al. 1992). Nitrate was reduced to nitrite with cadmium wires activated with a copper sulfate solution, and the nitrite was converted to pink azo dye for colorimetric determination. Concentrations of phosphate and silicate were measured using the Molybdenum blue and the silicomolybdenum blue methods (Strickland and Parsons 1972; Pai et al. 1990), respectively.

\subsection{Diatom, Copepod and Medusa Abundance}

To concentrate diatoms, a $500 \mathrm{ml}$ water sample was processed by the Utermöhl method. Diatom species were identified and counted using an inverted epifluorescence microscope (Nikon-Tmd 300) at 200x or 400x. The details of the procedure can be found in Chiang and Taniguchi (1993). Diatom and dinoflagellate cells with sizes $>10 \mu \mathrm{m}$ were counted. ANORPAC net with a $0.45-\mathrm{m}$ mouth and a $330-\mu \mathrm{m}$ mesh size was employed to collect the mesozooplankton. Collected samples were fixed with formaldehyde (final concentration is $5 \%$ ). The species composition and abundance of the copepods and the medusae were counted under a microscope (Nikon, SMZ800). References for identification of copepod species were Chihara and Murano (1997) and Shih (2009).

\section{RESULTS}

\subsection{Temperature, Salinity, and Nutrients}

Temperature $\left(18.5-29.7^{\circ} \mathrm{C}\right.$, Fig. 2a) varied seasonally with the lowest and highest values recorded in January and July, respectively. Spatially, temperature behaved homogeneously within each sampling period. Based on the annual temperature pattern, January, April, July, and October were defined as winter, spring, summer and autumn seasons respectively. Salinity (31.5 34.5 psu; Fig. 2c) also varied with seasonal temperature (Table 1). In some cases, salinity varied significantly among the stations in the same season. For example, spatial variance of the salinity was observed in July 2005, which might be due to higher river input. Silicate concentration varied $\sim 15$ fold (mean values $2.1-12.1 \mu \mathrm{M}$; Fig. 2a) annually and showed a significant seasonal trend 
(a)

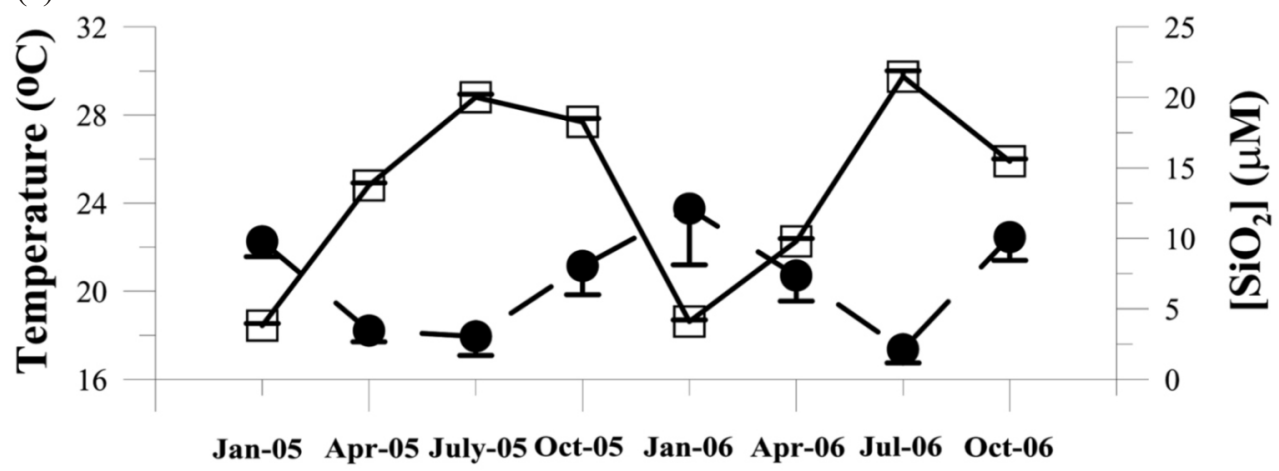

(b)
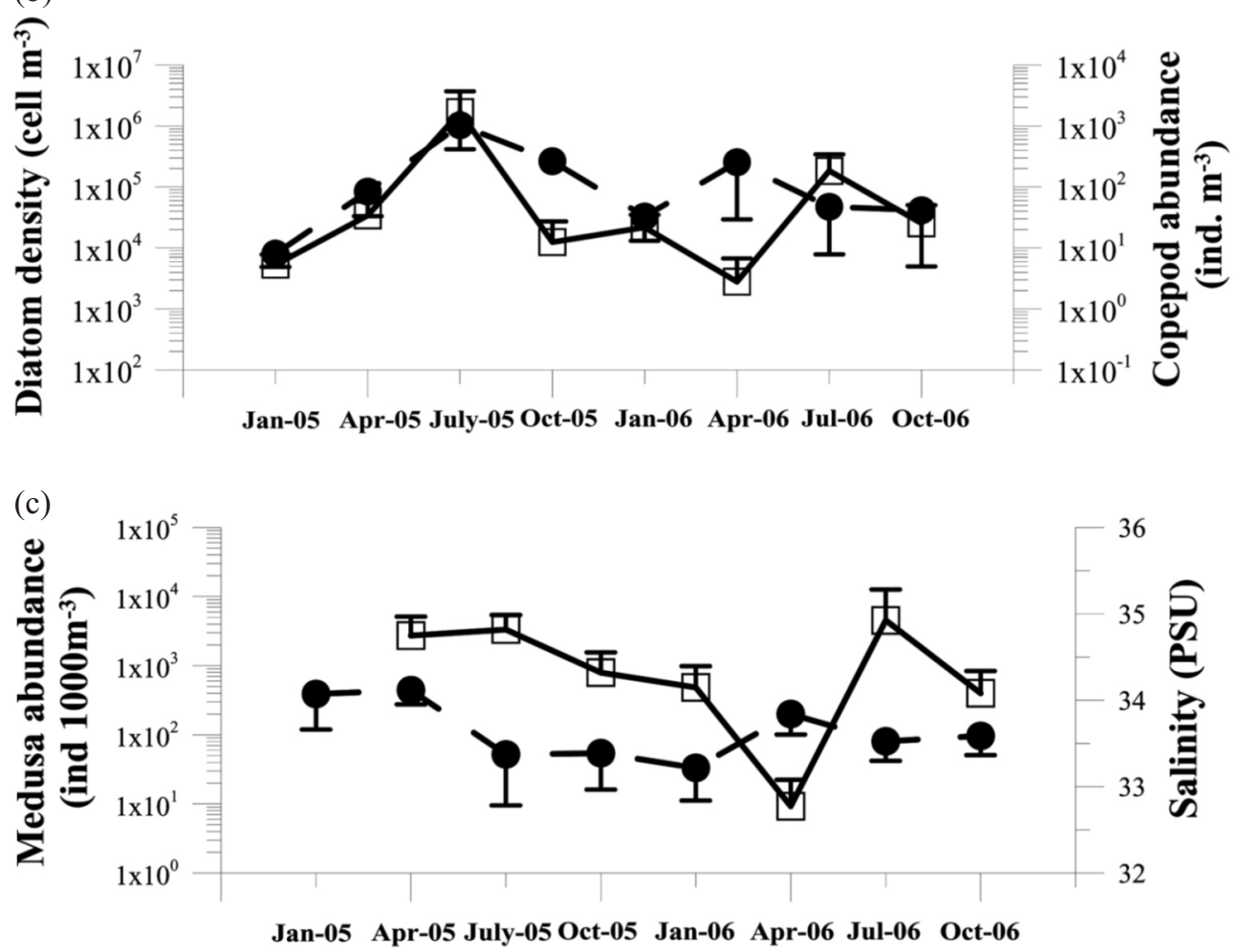

Fig. 2. Seasonal patterns of the mean values of (a) temperature ( $\square$ ) and silicate concentration (O), (b) Diatom density ( $\square$ ) and copepod abundance (๑), (c) medusa abundance $(\square)$ and salinity $(\bullet)$ collected in 2005 and 2006. Vertical bars indicated standard deviation.

Table 1. Correlation matrix of measurements using (A) all data, (B) 2005, and (C) 2006; ns, not significant at $p=0.01$ level, and dash lines, not analyzed.

\begin{tabular}{llccccc}
\hline Items & Units & Temperature & Salinity & Silicate & Diatoms & Copepods \\
\hline Temperature & ${ }^{\circ} \mathrm{C}$ & & & & \\
Salinity & $\mathrm{PSU}$ & $\mathrm{ns}$ & & & \\
Silicate & $\mu \mathrm{M}$ & -0.65 & -0.31 & & & \\
Diatoms & cells $\mathrm{m}^{-3}$ & +0.27 & $\mathrm{~ns}$ & -0.23 & & \\
copepods & inds. $\mathrm{m}^{-3}$ & +0.36 & $\mathrm{~ns}$ & - & +0.35 & $\mathrm{~ns}$ \\
Medusae & inds. $10^{-3} \mathrm{~m}^{-3}$ & +0.28 & $\mathrm{~ns}$ & - & $\mathrm{ns}$ \\
\hline
\end{tabular}


(Table 1) with higher values in the winter and lower values in the summer in both years of the study. The temporal and spatial patterns of the other two major nutrients, namely nitrate $(0.4-6.3 \mu \mathrm{M})$ and phosphate $(0.1-0.8 \mu \mathrm{M})$, were similar to those of silicate. The correlation coefficients (i.e., r) for nitrate vs. silicate and phosphate vs. silicate were $+0.83(\mathrm{n}=$ $152)$ and $+0.72(\mathrm{n}=152)$, respectively.

\subsection{Temporal (Seasonal and Inter-Annual) Variations in Abundance of Plankton Groups}

Phytoplankton was dominated ( $>90 \%$ in abundance) by diatoms, with dinoflagellates $\left(226-10029\right.$ cells m$^{-3}$ ) representing only $<10 \%$. Thus, in the presentation and analysis below, we consider diatoms to be representative of the total phytoplankton. The abundance of diatoms (mean values, $2792-1602437$ cells $\mathrm{m}^{-3}$ ) basically varied with temperature (Table 1), but with some notable differences between the two years (Fig. 2b). In 2005, the diatom abundance was low in winter, increased in spring, peaked in summer and decreased in autumn. A similar pattern was observed in 2006, with the exception that diatom abundance in spring (2792 \pm 3926 cell s m$^{-3}$ ) was three times lower than that in winter $\left(9184 \pm 13795\right.$ cells $\left.^{-3}\right)$. The second significant difference was inter-annual: the diatom abundance in July 2005 $\left(1602437 \pm 2016246\right.$ cells m$\left.^{-3}\right)$ was at least $8 X$ that in 2006 , when the mean abundance was $183680 \pm 159811$ cells m$^{-3}$ (ANOVA, $\mathrm{p}<0.05$ ).

The species composition of copepods was defined. In winter, Calanus sinicus, Undiluna vulgaris, Paracalanus parvus, Euchaeta concinna, Corycaeus affinis, and Acartia erythraea were the dominant species. The dominant species in the spring were Cosmocalanus darwini, Acrocalanus gibber, Paracalanus parvus, Temora turbinata, T discaudata, Corycaeus affinis, Onceae venusta. Temora turbinata was the most dominant species ( $>60 \%$ of abundance) in summer. Acrocalanus gibber, Centropage furcatus, Paracalanus parvus, Temora turbinata, and Cosmocalanus darwini were dominant in autumn. Copepod abundance ( 8 - 1031 ind. $\mathrm{m}^{-3}$; Fig. 2b) exhibited significant seasonality and varied by more than two orders of magnitude. Their abundance correlated positively with the abundance of diatoms and the temperature (Table 1). Their inter-annual difference was also notable, as revealed by the fact that the mean abundance of copepods in July $2006\left(47 \pm 40\right.$ ind. $\left.\mathrm{m}^{-3}\right)$ was only $7 \%$ of that in July 2005 (ANOVA, p < 0.05). Overall, the three most abundant genera of copepods were Temora, Paracalanus, and Calanus. Temora spp. correlated positively with temperature $(\mathrm{r}=+0.33, \mathrm{n}=152, \mathrm{p}<0.01)$ and the diatoms $(+0.40, \mathrm{n}=152, \mathrm{p}<0.01)$. The abundance of Temora spp. $(1$ 712 ind. $\mathrm{m}^{-3}$ ) was $70 \%$ of the copepod abundance in the summer, and was the most dominant copepods, representing $>$ $50 \%$ of the total copepod abundance. Paracalanus spp. (0.1 176 ind. $\left.\mathrm{m}^{-3}\right)$ also correlated positively with temperature $(\mathrm{r}=$
$+0.34, \mathrm{n}=152, \mathrm{p}<0.01)$ but not with the abundance of diatoms. They represented $>25 \%$ of the total copepod abundance in spring and autumn. Calanus spp. were not significantly correlated with temperature or the abundance of diatoms. They were dominant in winter and spring, but accounted for only $\sim 10 \%$ of total copepod abundance.

The mean medusa abundance $\left(0-3811 \times 10^{-3}\right.$ inds. $\left.\mathrm{m}^{-3}\right)$ changed more than three orders of magnitude during the investigation period (Fig. 2c). Medusa abundance varied positively with temperature (Table 1). It peaked in later spring and summer, decreasing thereafter to a minimum $(9 \pm$ $13 \times 10^{-3}$ inds. $\mathrm{m}^{-3}$ ) during spring, 2006. A notable upsurge ( $>400$ fold) of medusa abundance was recorded from the spring to the summer $\left(3811 \pm 7560 \times 10^{-3}\right.$ inds. $\left.\mathrm{m}^{-3}\right)$ of 2006 . Thereafter, the medusa abundance decreased again.

\subsection{Spatial Variations of Plankton Groups}

Spatial distribution of the abundance of diatoms and copepods revealed different relationships during the eight sampling periods. Datasets of the growing seasons, the summer and spring (Fig. 3), were used as illustrative examples. The remaining datasets are not shown here but will be included and analyzed in the next section. The distribution of copepods (Fig. 3e) almost followed that of diatoms (Fig. 3a) in spring, 2005. However, during the summer of 2005, the areas with high abundance of copepods (Fig. 3f) were within areas with a low density of diatoms (Fig. 3b), and vice versa. In spring 2006, high density diatoms (Fig. 3c) coalesced at the south of the study area while the copepods concentrated in the north-east. In the following summer, diatoms (Fig. 3d) aggregated in the south while their predators (Fig. 3h) accumulated in the north. Moreover, the abundance of Temora spp. was negatively correlated with diatoms $(\mathrm{r}=+0.78, \mathrm{n}=$ $13, \mathrm{p}<0.01)$ and medusae $(\mathrm{r}=+0.64, \mathrm{n}=13, \mathrm{p}<0.01)$, such that the abundance of these three plankton groups was logtransformed. Similar results were obtained regarding the relationships of total copepods vs. diatoms and total copepods vs. medusae. Overall, the spatial patterns of copepods and phytoplankton during the growing seasons were in phase in 2005 , but out of phase in 2006. The coupling and decoupling of copepods and phytoplankton, in terms of spatial distribution and seasonal pattern, may be affected by the distribution of the top predator, the medusae (Figs. 3i $\sim 1$; see more below).

\subsection{Tropho-Dynamics and Cascading Effects}

Table 1 indicates that, overall, the temporal and spatial variation of the abundance of diatoms was positively correlated with that of copepods. Further analysis suggested that the predator-prey relationship was different inter-annually. Figure 4 revealed a significant correlation between diatom and copepod distributions only in $2005(\mathrm{r}=+0.66, \mathrm{n}=76$, 

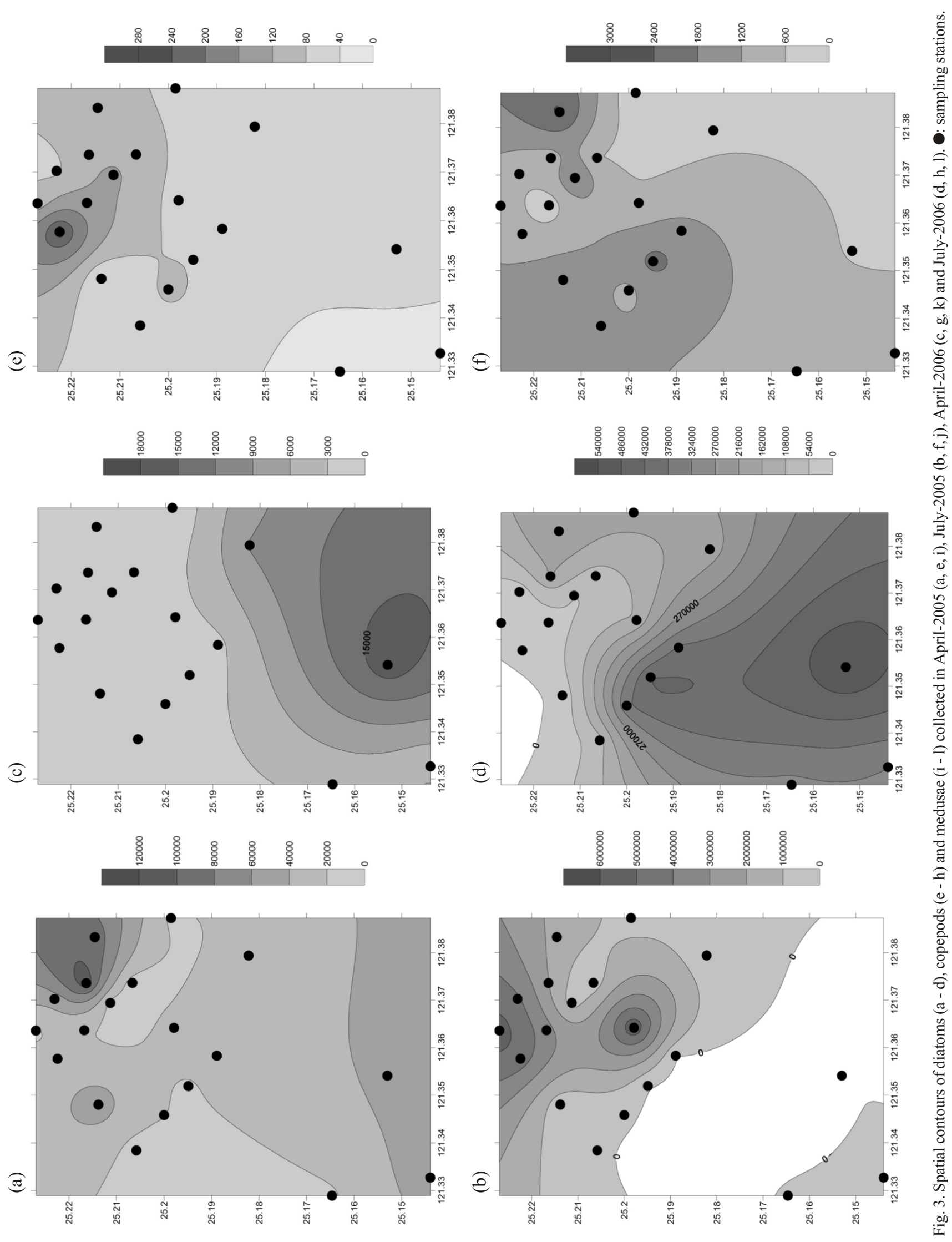

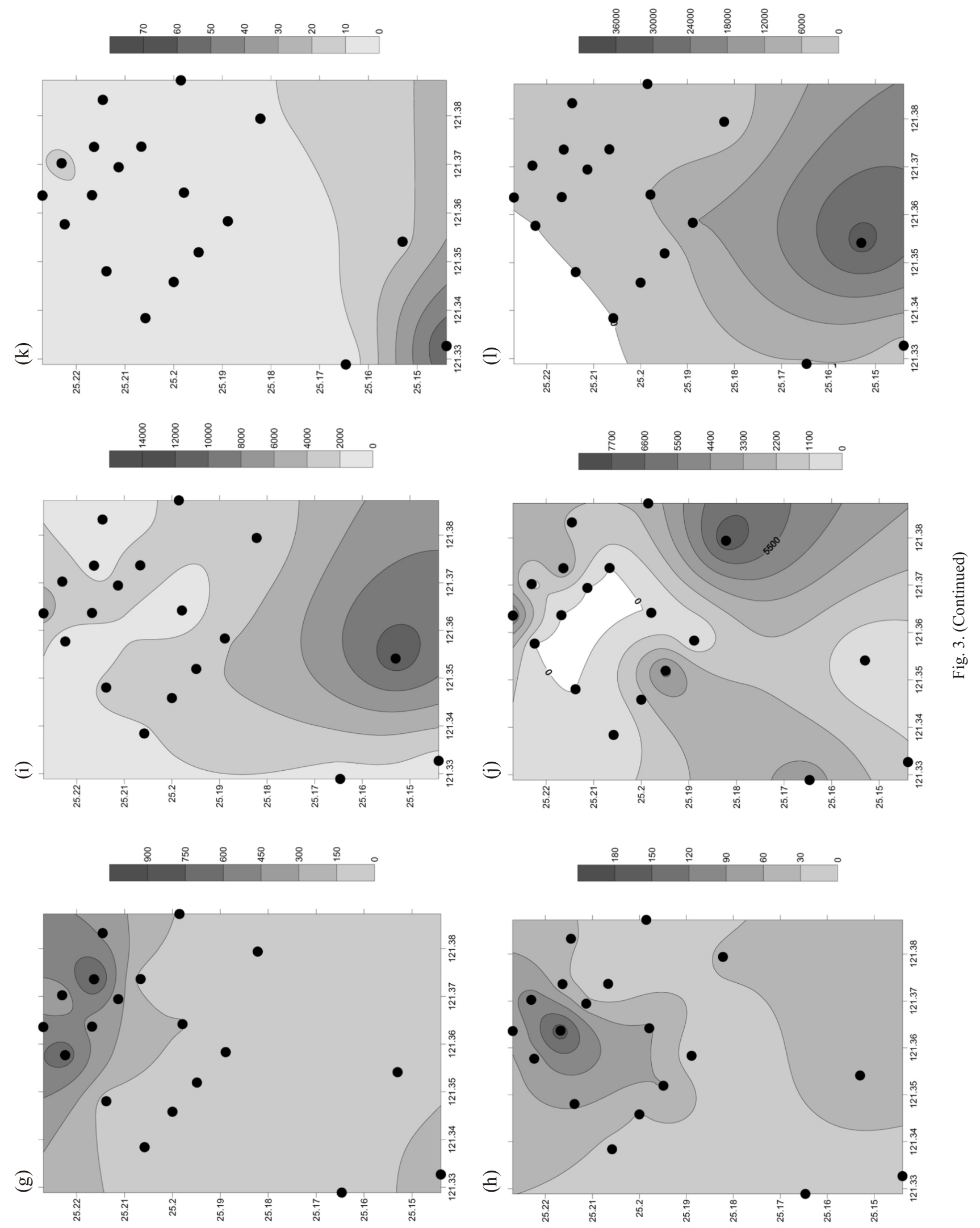


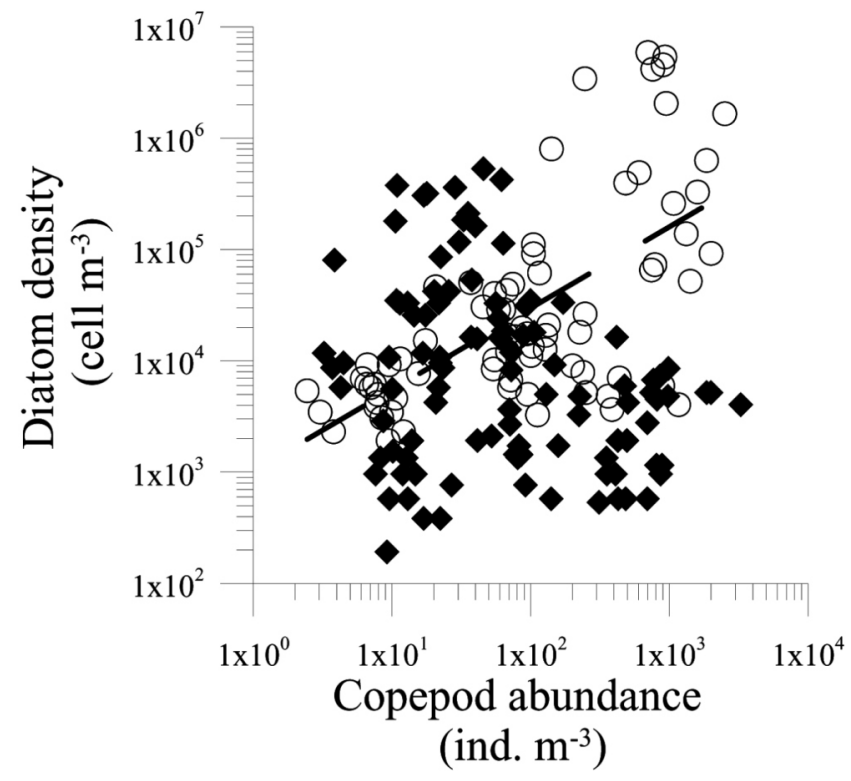

Fig. 4. A scatter plot of diatom abundance to copepod abundance using 2005 (solid circles) and 2006 (open diamonds) datasets. Dashed line indicated a regression of $\operatorname{Ln}(Y)=1.30( \pm 0.82)+0.56( \pm 0.08) \times \operatorname{Ln}(X), n$ $=76, \mathrm{r}^{2}=0.44, \mathrm{p}<0.01$.

$\mathrm{p}<0.01$ ), but not in the consecutive year. The rate of increase of the net abundance due to temperature is compared with the rate of decrease of the net abundance of these two planktons during the shift-up (2005 winter $\sim 2005$ summer) and shift down (2005 summer $\sim 2006$ winter) phases. The results indicate that the temperature-normalized rates of increase all exceeded (46\% for diatoms, 29\% for copepods, and 35\% for Temora spp.) the corresponding rates of decrease (Table 2).

The variation of medusa abundance seemed to regulate the seasonal and spatial relationships between copepods and diatoms (i.e., cascading effects). We calculated the ratios of diatoms to copepods (i.e., the ratios), and then plotted the ratios to medusae abundance. The initial results (Fig. 5) seemed to be quite random. However, individual (season by season) analysis indicates that during the periods medusae varied little (i.e., < 10-fold) between two consecutive seasons; no significant relationship existed between the ratios and the medusa abundance. Significant results appeared dur- ing the period of winter $\sim$ summer 2006 (Fig. 2c) when the medusae varied greatly from one season to the next. In 2006, the medusa abundance decreased by a factor of $\sim 43$ from winter $\left(383 \pm 480 \times 10^{-3}\right.$ inds. $\left.\mathrm{m}^{-3}\right)$ to spring $(9 \pm 13 \times$ $10^{-3}$ inds. $\mathrm{m}^{-3}$ ), and the ratios simultaneously decreased from $611 \pm 951$ to $25 \pm 44$ diatoms copepods $^{-1}$. As the medusae proliferated by a factor of $\sim 411$ from spring to summer (3811 $\pm 7650 \times 10^{-3}$ inds. $\mathrm{m}^{-3}$ ), the ratios increased from $25 \pm 44$ to $8591 \pm 9442$ diatoms copepods $^{-1}$.

\section{DISCUSSION AND CONCLUSIONS}

The study area was a meso- to eutrophic system, as judged from high annual mean nitrate $(3.7 \pm 2.3 \mu \mathrm{M})$, phosphate $(0.42 \pm 0.29 \mu \mathrm{M})$ and silicate $(7.0 \pm 4.0 \mu \mathrm{M})$ concentrations. The climate in northern Taiwan can be regarded as wet in the summer and dry in the winter. In the summer, prevailing southwest monsoon and episodic typhoons are the major driving factors for high precipitation and, therefore, higher river discharge. Summer river discharge data in 2006 were not available from the Taiwan Water Resource Bureau since the monitor used to measure the flow rate malfunctioned for two months. Precipitation data were used alternatively in the discussion of the potential impacts of the river (source, Taiwan Weather Bureau).

The species identified in this work compare favorably with those in previous studies conducted in this estuary (Hsieh and Chiu 1997; Hwang et al. 2006). Temora spp. are very common herbivores in coastal ecosystems (Valentin et al. 1987; Ortner et al. 1989; Ianora and Poulet 1993; Nielsen et al. 1993, Gislason and Astthorsson 1995; Ragosta et al. 1995; Suárez-Morales and Gasca 1996). They are generally more abundant in warmer seasons (Mazzocchi and Ribera d'Alcalà 1995; Hsieh and Chiu 1997; Ribera d'Alcalà et al. 2004; Hwang et al. 2006). Temora spp. have a feeding preference for diatoms, particularly during the season of phytoplankton growth (Turner 1984). The result of an in situ feeding study shows that Temora spp. grazed $50 \%$ of the phytoplankton biomass (calculated by chlorophyll $a$ concentration) per day in this estuary (Chung, unpublished data).

In natural environments, all living organism are well known to be subjected to physical, chemical and biological

Table 2. Slope values calculated from the linear regression of planktons' abundance vs. temperature during the shift-up and shift-down phases. See text for explanation.

\begin{tabular}{llccc}
\hline Planktons & \multicolumn{1}{c}{ Units } & Shift-up & Shift-down & Difference (\%) $^{\text {****}}$ \\
\hline Diatoms & $\times 10^{3}$ cells m $^{-3}{ }^{\circ} \mathrm{C}^{-1}$ & $140 \pm 38^{*}$ & $96 \pm 38^{*}$ & 46 \\
Copepods & inds. $\mathrm{m}^{-3}{ }^{\circ} \mathrm{C}^{-1}$ & $90 \pm 13$ & $70 \pm 14$ & 29 \\
Temora sp. & inds. $\mathrm{m}^{-3}{ }^{\circ} \mathrm{C}^{-1}$ & $62 \pm 12^{* *}$ & $47 \pm 13^{* *}$ & 35 \\
\hline
\end{tabular}

* and **: Significantly different from each other by ANCOVA test at 0.01 level.

$* * *$ : Calculated as [(shift-up slope - shift-down slope) $/$ shift-down slope $] \times 100 \%$. 


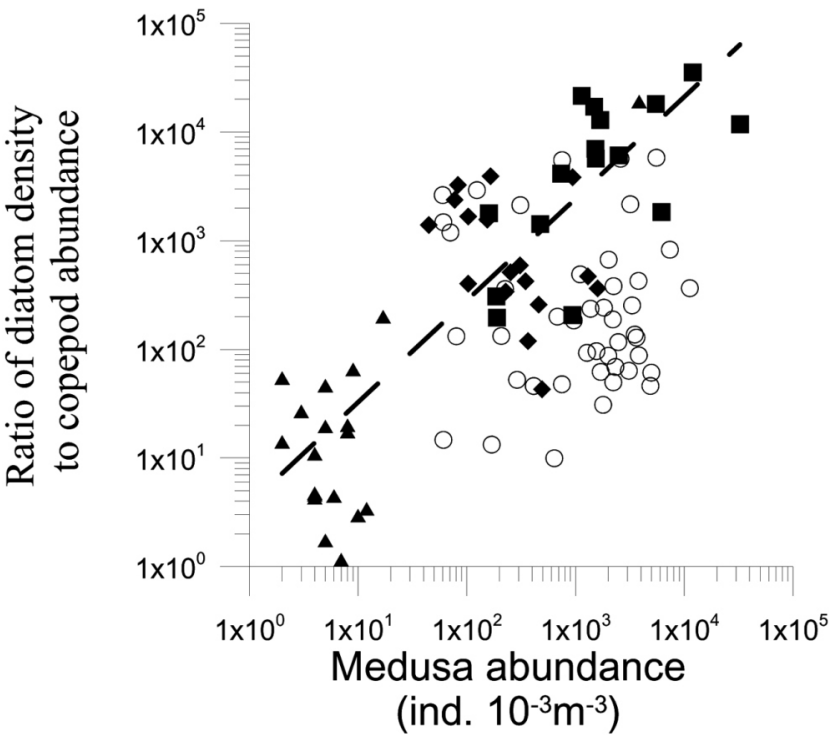

Fig. 5. A scatter plot of the ratio of diatom abundance to copepod abundance vs. medusa abundance. Symbols solid diamonds, solid triangles and solid squares represented winter, spring and summer 2006, respectively. Dashed line, $\operatorname{Ln}(\mathrm{Y})=1.21( \pm 0.48)+0.95( \pm 0.89) \times \operatorname{Ln}(\mathrm{X})$ $\left(\mathrm{n}=58, \mathrm{r}^{2}=0.67, \mathrm{p}<0.01\right)$ from spring to summer 2006 .

controls. An enhancement or reduction of biomass reflects the net result of these rate-limiting processes. The strong temperature dependence of diatoms and copepods (Table 1) indicates that their growth may be restricted more by interactions between temperature and top-down processes than by bottom-up control (nutrient and food supply) processes. Our argument for the temperature, but not substrate (or food) supply, control on plankton seasonality was based on the reasoning that temperature effects would not occur if their growth was limited by the food supply, since all living organisms feed on materials, but not on temperature (Shiah and Ducklow 1994). Previous studies have demonstrated that bottom-up control processes and biogeochemical processes in coastal and estuary system seldom control the growth of many planktons, including bacteria (Shiah et al. 2006), protozoans (Sherr and Sherr 2002) and copepods (Calbet 2001; Calbet and Saiz 2005).

The significant seasonal behavior of diatoms might also be affect by seasonal light intensity, which is in parallel to the change of temperature. A much lower diatom density was recorded in spring 2006 then that in spring 2005. In spring 2006, residual silicate concentration $(7.4 \pm 1.8 \mu \mathrm{M})$ was $3.9 \mu \mathrm{M}$ higher than in 2005 and temperature $\left(22.3^{\circ} \mathrm{C}\right)$ was $2.5^{\circ} \mathrm{C}$ lower. Moreover, the daily light intensity $\left(13.8 \mathrm{mEins} \mathrm{m}^{-2} \mathrm{~d}^{-1}\right)$ in April 2006 was $80 \%$ of that in 2006, and the densities of the copepods in $2006\left(254 \pm 225\right.$ inds. $\left.\mathrm{m}^{-3}\right)$ were three times higher than those of their counterparts in $2005\left(84 \pm 51\right.$ inds. $\left.\mathrm{m}^{-3}\right)$, supporting the conclusion that worse environmental conditions (lower temperature, lower light intensity and more grazers) did not favor the growth of diatoms, but led to a lower diatom abundance and higher ambient silicate concentrations in spring 2006. Moreover, the significant inter-annual difference $(>8 \mathrm{X})$ of summer diatom abundance may result from of the variation in the precipitation. The total precipitation three weeks before July 2005 (101 mm) was $40 \%$ higher than that of July 2006, in which precipitation was $61 \mathrm{~mm}$ (data source, Central Weather Bureau of Taiwan). Greater river discharge that was caused by more precipitation may bring more nutrients into the study site. Those nutrients input might support more environmental carrying capacity in summer 2005, when diatom density was higher than that in 2006, despite the fact that copepod abundance was 20 times more in summer 2005 $\left(1031 \pm 615\right.$ inds. $\left.\mathrm{m}^{-3}\right)$ than that in $2006\left(47 \pm 39\right.$ inds. $\left.\mathrm{m}^{-3}\right)$.

Next to temperature effects, top-down control processes may be the secondary dominant factor in regulating the seasonal and temporal patterns of plankton. The results suggest that the relative importance of top-down control on phytoplankton abundance may be different in the shift-up and shift-down phases (Table 2). During the shift-up period, the increasing temperature (and light intensity) stimulated the growth of algae, and their growth rate must have exceeded the concurrent grazing rate to cause net accumulation of biomass. On the other hand, decreasing physical conditions might have inhibited algal growth during the shift-down period. Three possible explanations can be given. First, temperature stimulation (during the shift-up phase) may be more effective than temperature inhibition. Second, grazing pressure was less intense during the shift-down phase. Finally, the copepod grazing rate was reduced by lower temperature in the shift-down phase. The slopes in Table 2 were normalized by temperature, based on the assumption that physiological stimulating and inhibiting effects that were induced by temperature (or light intensity) were equal in both phases. Under this scenario, the lower grazing pressure in the shiftdown phase plausibly explains the much slower decrease in the phytoplankton abundance during this period. Moreover, the decrease in the specific grazing rate caused by the decrease in temperature may also reduce grazing pressure. This suggestion is arguable because only one-cycle of analysis was conducted. However, the interpretation is reasonable since the same phenomenon occurred at the zooplankton level.

Many studies have demonstrated that medusae can cause a shift in the trophic structure of the pelagic community as a result of trophic cascading (Behrends and Schneider 1995; Schneider and Behrends 1998; Stibor et al. 2004 and citations therein). However, many of these published studies have addressed the effects of cascading effects on the temporal variability of lower trophic levels. The results demonstrate that medusa variability can strongly influence the spatial and temporal variations of the ecological relationship (i.e., the ratios) between diatoms and copepods. In an environment in which the abundance of top predators (trophic level 3 , medusae) and thus their grazing pressures on trophic 
level 2 (copepods) did not vary from season to season, such as in the cases of 2005, planktons of the lower two trophic levels may oscillate simultaneously under steady cascading control. In the sense of trophic cascading, one might say that the ecological relationships of the two lower trophic levels were free of the control exerted from trophic level 3. This fact may be one of the major reasons for the absence of a relationship between the ratios and the medusa abundance when the medusa abundance did not change significantly season by season. On the other hand, when the abundance of the top predators rapidly decreased or increased, their grazing pressure on trophic level 2 might have been significantly reduced or intensified such that a notable change of the ratios of the lower trophic levels was observed.

In conclusion, the dependence of phytoplankton and mesozooplankton abundances on temperature was strong in this area. Base on this dependency, bottom-up control may be weak, while top-down control is more important to the temporal and spatial variations of the planktons. The very large observed changes in medusa abundance that caused cascading effects affected not only temporally but also spatially on the relationship between diatoms and copepods. This huge change also affected copepod variation. A positive relationship between the lower two trophic levels occur when the abundance of the top predator varies insufficiently (i.e., $<10$-fold), potentially yielding stable diatom to copepod ratios.

Acknowledgement We are grateful to the assistance of crew of the R/V Ocean Research II, Xu Chen and Sinotech Engineering Consultants, LTD. The research was funded by the National Science Council of Taiwan (NSC96-2621Z-019-001-MY2). The research was also, in parts, supported by the Center for Marine Bioscience and Biotechnology at NTOU.

\section{REFERENCES}

Bautista, B. and R. P. Harris, 1992: Copepod gut content, ingestion rates and grazing impact on phytoplankton in relation to size structure of zooplankton and phytoplankton during spring bloom. Mar. Ecol. Prog. Ser., 82, 41-50, doi: 10.3354/meps082041. [Link]

Behrends, G. and G. Schneider, 1995: Impact of Aurelia aurita medusae (Cnidaria, Scyphozoa) on the standing stock and community composition of mesozooplankton in the Kiel Bight (western Baltic Sea). Mar. Ecol. Prog. Ser., 127, 39-45, doi: 10.3354/meps127039. [Link]

Calbet, A., 2001: Mesozooplankton grazing effect on primary production: A global comparative analysis in marine ecosystems. Limnol. Oceanogr., 46, 824-1830.

Calbet, A and E. Sainz, 2005: The ciliate-copepod link in marine ecosystems. Aquat. Micorb. Ecol., 38, 157-167, doi: 10.3354/ame038157. [Link]

Chiang, K. P. and A. Taniguchi, 1993: Formation of a diatom assemblage distribution widely in the North Pacific Polar
Frontal Zone. Bukk. Jpn. Soc. Fish. Oceanogr., 57, $307-$ 318.

Chihara, M. and M. Murano, 1997: An illustrated Guide to Marine Plankton in Japan. Tokai University, Japan, 649-1004.

Cushing, D. H., 1989: A difference in structure between ecosystems in strongly stratified waters and those that are only weakly stratified. J. Plankton Res., 11, 1-13, doi: 10.1093/ plankt/11.1.1. [Link]

Dagg, M. J., 1995: Ingestion of phytoplanktob by the microand mesozooplankton communities in a productive subtropical estuary. J. Plankton Res., 17, 845-857, doi: 10.1093/ plankt/17.4.845. [Link]

Davis, C. S., 1987: Zooplankton life cycles. In: Backus, R. H. (Ed.), Georges Bank, Massachusetts Institute of Technology, Cambridge, MA, 256-267.

Dur, G., J. S. Hwang, S. Souissi, L. C. Tseng, C. H. Wu, S. H. Hsiao, and Q. C. Chen, 2007: An overview of the influence of hydrodymaics on the spatial and temporal patterns of calanoid copepod communities around Taiwan. J. Plankton Res., 29, i97-i116, doi: 10.1093/plankt/fbl070. [Link]

Fang, T. H., J. S. Hwang, S. H. Hsiao, and H. Y. Chen, 2006: Trace metals in seawater and copepods in the outfall area off the northern Taiwan coast. Mar. Environ. Res., 61, 224-243, doi: 10.1016/j.marenvres.2005.10.002. [Link]

Froneman, P. W., 2000: Feeding studies on selected zooplankton in a temperate estuary, South Africa. Estuar. Coast. Shelf Sci., 51, 543-552, doi: 10.1006/ecss.2000.0700. [Link]

Froneman, P. W., 2001: Seasonal changes in zooplankton biomass and grazing in a temperate estuary, South Africa. Estuar. Coast. Shelf Sci., 52, 543-553, doi: 10.1006/ecss. 2001.0776. [Link]

Gislason, A. and O. S. Astthorsson, 1995: Seasonal cycle of zooplankton Southwest of Iceland. J. Plankton Res., 17, 1959-1976, http://dx.doi.org/10.1006/ecss.2001.0776. [Link]

Gong, G. C., C. Z. Shyu, W. H. Shin, and K. K. Liu, 1992: Temperature fluctuation of the cold water off northern Taiwan. Acta Oceanogr. Taiwan., 21, 1-17.

Hsieh, C. H. and T. S. Chiu, 1997: Copepod abundance and species composition of Tanshui River estuary and adjacent waters. Acta. Zool. Taiwan., 8, 75-83.

Hwang, J. S., Q. C. Chen, and C. K. Wong, 1998: Taxonomic composition and grazing rate of calanoid copepods in coastal waters of northern Taiwan. Crustaceana, 71, 378389, doi: 10.1163/156854098X00491. [Link]

Hwang, J. S., S. Souissi, L. C. Tseng, L. Seuront, F. G. Schmitt, L.-S. Fang, S.-H. Peng, C.-H. Wu, S. H. Hsiao, W.-H. Twan, T.-P. Wei, R. Kumar, T.-H. Fang, Q.-C. Chen, and C. K. Wong, 2006: A 5-year study of the influence of the northeast and southwest monsoons o copepod assemblages in the boundary coastal waters between the East China Sea and the Taiwan Strait. J. Plankton Res., 28, 943-958, doi: 10.1093/plankt/fbl031. [Link]

Ianora, A. and S. A. Poulet, 1993: Egg viability in the copepod 
Temora stylifera. Limnol. Oceanogr., 38, 1615-1626.

Liu, H. B. and M. Dagg, 2003: Interactions between nutrients, phytoplankton growth, and micro- and mesozooplankton grazing in the plume of the Mississippi River. Mar. Ecol. Prog. Ser., 258, 31-42, doi: 10.3354/meps258031. [Link]

Matsakis, S. and R. J. Conover, 1991: Abundance and feeding of medusae and their potential impact as predators on other zooplankton in Bedford Basin (Nova Scotia, Canada) during spring. Can. J. Fish. Aquat. Sci., 48, 1419-1430, doi: 10.1139/f91-169. [Link]

Mazzocchi, M. G. and M. R. d'Alcalà, 1995: Recurrent patterns in zooplankton structure and succession in a variable coastal environment. ICES J. Mar. Sci., 52, 679-691, doi: 10.1016/1054-3139(95)80081-6. [Link]

McLaren, I. A., M. J. Tremblay, C. J. Corkett, and J. C Roff, 1989: Copepod production on the Scotian Shelf based on life-history analyses and laboratory rearings. Can. J. Fish. Aquat. Sci., 46, 560-583.

Nielsen, A., A. Pedersen, and H. U. Riisgard, 1997: Implications of density driven currents for interaction between jellyfish (Aurelia aurita) and zooplankton in a Danish fjord. Sarsia, 82, 297-305.

Nielsen, T. G., B. Løkkegaard, K. Richardson, F. B. Pedersen, and L. Hansen, 1993: Structure of plankton communities in the Dogger Bank area (North Sea) during a stratified situation. Mar. Ecol. Prog. Ser., 95, 115-131, doi: 10.3354/ meps095115. [Link]

Olesen, N. J., 1995: Clearance potential of jellyfish Aureliaaurita, and predation impact on zooplankton in a shallow cove. Mar. Ecol. Prog. Ser., 124, 63-72, doi: 10.3354/ meps 124063. [Link]

Ortner, P. B., L. C. Hill, and S. R. Cummings, 1989: Zooplankton community structure and copepod species composition in the northern Gulf of Mexico. Cont. Shelf Res., 9, 387402, doi: 10.1016/0278-4343(89)90040-X. [Link]

Pai, S. C., C. C. Yang, and J. P. Reliey, 1990: Formation kinetics of the pink azo dye in the determination of nitrite in natural waters. Anal. Chim. Acta, 232, 345-349, doi: 10.1016/ S0003-2670(00)81252-0. [Link]

Purcell, J., 1992: Effects of predation by the scyphomedusa Chrysaora quinquecirrha on zooplankton populations in Chesapeake Bay, USA. Mar. Ecol. Prog. Ser., 87, 65-76.

Ragosta, M., G. M. Mazzocchi, and M. Macchiato, 1995: Differentiation of copepod assemblages in coastal waters of the Tyrrhenian Sea. Oceanol. Acta, 18, 479-491.

Ribera d'Alcalà, M., F. Coversano, F. Corato, P. Licando, O. Mangoni, D. Marino, M. G. Mazzochi, M. Modigh, M. Montresor, M. Nardella, V. Saggiomo, D. Sarno, and A. Zingone, 2004: Seasonal patterns in planktonic communities in a pluriannual time series at a coastal Mediterranean site (Gulf of Naples): An attempt to discern recurrences and trends. Sci. Mar., 68, 65-83.

Runge, J. A., 1988: Should we expect a relationship between primary production and fisheries? The role of copepod dynamics as a filter of trophic variability. Hydrobiologia,
167/168, 61-71, doi: 10.1007/BF00026294. [Link]

Sautour, B., F. Artigas, A. Herbland, and P. Laborde, 1996: Zooplankton grazing impact in the plume of dilution of the Gironde estuary (France) prior to the spring bloom. $J$. Plankton Res., 18, 835-853, doi: 10.1093/plankt/18.5.835. [Link]

Sautour, B. and J. Castel, 1999: Grazing activity of mesoplanktonic copepods in a shallow bay during an algal spring bloom (Marennes-Oléron Bay, France). J. Mar. Biol. Ass. $U K, 79,73-84$, doi: 10.1017/S0025315498000083. [Link]

Schneider, G. and G. Behrends, 1994: Population dynamics and the trophic role of Aurelia aurita medusae in the Kiel Bight and western Baltic. Ices J. Mar. Sci., 51, 359-367, doi: 10.1006/jmsc.1994.1038. [Link]

Schneider, G. and G., Behrends, 1998: Top-down control in a neritic plankton system by Aurelia aurita medusae - A summary. Ophelia, 48, 71-82.

Sherr, E. B. and B. F. Sherr, 2002: Significance of predation by protists in aquatic microbial food webs. Antonie van Leeuwenhoek, 81, 293-308, doi: 10.1023/A:1020591307260. [Link]

Shiah, F. K. and H. W. Ducklow, 1994: Temperature and substrate regulation of bacterial abundance, production and specific growth rate in Chesapeake Bay, USA. Mar. Ecol. Prog. Ser., 103, 297-308, doi: 10.3354/meps103297. [Link]

Shiah, F. K., T. H. Wu, K. Y. Li, S. J. Kao, Y. F. Tseng, J. L. Chung, and S. Jan, 2006: Thermal effects on heterotrophic processes in a coastal ecosystem adjacent to a nuclear power plant. Mar. Ecol. Prog. Ser., 309, 55-65, doi: 10.3354/meps309055. [Link]

Shih, C. T., 2009: Keys to the genera and species of copepod families occurring in the marginal sea of China, 1-69, in press.

Stibor, H., O. Vadstein, S. Diehl, A. Gelzleichter, T. Hansen, F. Hantzsche, A. Katechakis, B. Lippert, K. Løseth, C. Peters, W. Roederer, M. Sandow, L. S. Hansen, and Y. Olsen, 2004: Copepods act as a switch between alternative trophic cascades in marine pelagic food webs. Ecol. Lett., 7, 321328, doi: 10.1111/j.1461-0248.2004.00580.x. [Link]

Strickland, J. D. H. and T. R Parsons, 1972: A practical handbook of seawater analysis. Fisheries Research Board of Canada, Ottawa, 1-360.

Suárez-Morales, E. and R. Gasca, 1996: Planktonic copepods of Bahia de la Ascension, Caribbean coast of Mexico: A seasonal survey. Crustaceana, 69, 162-174, doi: 10.1163/ 156854096X00484. [Link]

Turner, J. T., 1984: Zooplankton feeding ecology: Contents of facal pellets of the copepods Temora turbinata and T. stylifera from continental shelf and slope waters near the mouth of the Mississippi River. Mar. Biol., 82, 73-83, doi: 10.1007/BF00392765. [Link]

Valentin, J. L., W. M. Monteiro-Ribas, M. A. Mureb, and E. Pessotti, 1987: Sur quelques zooplanctontes abondants dans l'upwelling de Cabo Frio (Brésil). J. Plankton Res., 9 1195-1216, doi: 10.1093/plankt/9.6.1195. [Link] 